FILOLOGÍA HISPÁNICA 



\section{NOTAS DE FILOLOGÍA ESPAÑOLA JUAN RUIZ, EL SIGLO XV, EL BARROCO, LAPESA}

FRANCISCO ABAD

UNED

fabad@flog.uned.es

\section{RESUMEN}

Tratamos de la sucesión estilística de épocas clasicistas (épocas A), y épocas de complicación elocutiva (B). También de la Historia de la lengua de Lapesa.

Palabras Clave: Juan Ruiz, Marqués de Santillana, Juan de Mena, Barroco, Rafael Lapesa.

RÉSUMÉ

Dans cet article on aborde la question de la succession stylistique d'époques classiques (époques A) et d'époques de complication de l'élocution (époques B). On aborde également l'Histoire de la langue de Lapesa.

Mots-Clefs: Juan Ruiz, Marqués de Santillana, Juan de Mena, Barroco, Rafael Lapesa.

I. JuAN Ruiz; ASPECTOS DEL SIGLO XV

\section{Crisis histórica y estilos de época: el Arcipreste de Hita}

La época de Juan Ruiz es una fase B o de depresión de la historia; en la complejidad de los hechos, Menéndez Pidal estima que se da por entonces una «corriente de tradicio- 
nalidad idiomática» dominante, «una época de naturalidad», aunque concede que Juan Ruiz resulta «neologista»; estamos por tanto ante estilos de naturalidad que en principio se estima que no se corresponden con las fases B sino con las A (expansivas y clasicistas). No obstante creemos en el caso del Arcipreste que en algo tiende a los estilos B, a la complicación y complejidad estilística: estamos ante un extraordinario creador de estilo: Juan Ruiz —en palabras pidalinas— «se entrega a la expresión de su propio estado de ánimo, a la oportunidad del instante transitorio [...]; Juan Ruiz cultiva la imprecisión emocional» (2005, I, pp. 560, 566, 568, 570, y 575).

Los estudiosos siguen a Carmelo Gariano, quien efectivamente señala estos hechos en la obra:

a) la «redundancia verbal» o «amontonamiento de términos sinónimos»

b) el uso de diminutivos, con diferentes significaciones: gracejo cariñoso; compasión; pintoresquismo; situación de desamparo;... «De todos modos [...] nuestro autor es muy parsimonioso en el empleo de este morfema».

c) la enumeración

d) presencia de máximas y refranes

e) lo que podemos llamar «decoro»: «El Arcipreste nunca pone en boca de personajes de baja condición social dichos elevados o citas cultas».

f) símiles (Gariano, 1974, cap. V).

En síntesis tenemos una época histórica de crisis (B), y en el estilo literario momento de claridad y de la llamada naturalidad (A), aunque en el caso del Arcipreste de Hita creemos que hay una dificultad o recarga de estilo más propia de las fases B.

\section{Una nueva poética cultista y latinizante (I)}

Nuestro Cuatrocientos se distinguió en el estilo verbal por su consciencia innovadora en un sentido cultista latinizante y a veces de oscuridad: a esta centuria seguirá la del Dieciséis que se le opone por la claridad elocutiva. La situación idiomática del XV la concretó ya Menéndez Pidal en sus páginas del año 33 —empezaba a dejar entonces por escrito su dedicación a la Historia de la lengua-, cuando enseñaba:

En el siglo XV cae uno de esos períodos de gran anhelo por la innovación verbal, buscada sobre todo en el cultismo. Entre caballeros y escuderos se había hecho moda el estudio del latín, y eso nos explica el estilo de D. Enrique de Villena, del Marqués de Santillana, de Rodríguez del Padrón, de Juan de Mena. El latinismo de léxico, de sintaxis [...] invadía por todas partes, sin que el idioma pudiese digerirlo ni asimilarlo, y de esta manera así se ve de modo particular en Juan de Mena, etc. (Menéndez Pidal, 1933, p. 18).

Los escritores cuatrocentistas instauraban una poética según la cual el mensaje llamaba la atención por sí mismo, mas lo hacían latinizándolo con abuso apenas tolerable por el idioma; el espesor del discurso era muy notable, pero no ajustado a la índole de la lengua; la manera de expresarse de un Garcilaso por ej. será muy otra.

El castellano en efecto - testimonia por su lado Jaime Oliver- no pudo asimilar tan gran número y carga de latinismos, «ni menos forzar desmesuradamente su sintaxis tradicional», por lo que esas extravagancias exageradas fracasaron (Oliver, § 67); de hecho, los experimentos cuatrocentistas no debieron de incidir mucho en la lengua ordinaria, aunque sí en la que se estimaba artística. 
Alguna vez se ha recordado a este respecto lo que expresó don Enrique de Villena acerca de cómo se encontraba limitado — en su «traslado de latin en romançe castellano de la eneyda de uirgilio»—, por no «equjualentes fallar uocablos en la romançial texedura para exprimjr aquellos angelicos conçebimjentos virgilianos» (Santiago, 1979, p. 33), esto es, por el escepticismo acerca del valor de la lengua vulgar.

De c. 1439 se tiene que es el texto en prosa de Juan de Mena La coronación del Marqués de Santillana, el cual lleva a su principio varios Preámbulos en el segundo de los cuales se estiman los «estilos» en cuanto «géneros». Expresa el poeta:

Sepan los que lo ignoran que por alguno de tres estilos escriven o escrivieron los poetas: por estilo trágico, sátiro o comedio. Tragedia es dicha la escritura que fabla de altos fechos, e por bravo e sobervio e alto estilo, la qual manera seguieron Omero, Vergilio, Lucano, Estaçio; por la tragedia escritura, puesto que comiença en altos prinçipios, su manera es acabar en tristes e desastrados fines. Sátira es segundo estilo de escrivir, la naturaleza de la qual escritura e ofiçio reprehende los viçios, del qual estilo usaron Oraçio, Persio e Juvenal. El terçero estilo es comedia, la qual tracta de cosas baxas e pequeñas, e por baxo e omilde estilo, e comiença en tristes prinçipios e fenesçe en alegres fines, del qual usó Terençio (Mena, 1989, p. 107).

Hay un estilo alto y otro bajo consustanciales con la tragedia y la comedia respectivamente, y se comprueba cómo por estilo se entiende no ya sólo la manera elocutiva, sino una verdadera tipología de géneros o subgéneros. No nos hallamos ante una sola división en tres clases de elocución, sino ante la división en tres especies de géneros: el de la tragedia (que tiene alto principio y triste fin, y además se caracteriza por el alto estilo elocutivo), el de la sátira (que censura los vicios), y el de la comedia, la cual tiene un principio triste y el final alegre y —además — se halla compuesta en elocución baja y humilde.

Un poco posterior a «La Coronación...» es La Ilíada en romance del propio Mena, en la que nuestro poeta alude a las lenguas griega y latina y en contraste con ellas, la castellana le parece un «rudo y desierto romance», una «umillde y baxa lengua» (Ibid., p. 334). La estimación del idioma y la poética del Cuatrocientos es ya distinta a la de las centurias precedentes: ahora la mayor elevación se atribuye a los idiomas clásicos, y no cabrá sino latinizar en las obras literarias el idioma vernáculo para darle así dignidad.

Acostumbran a decir los autores —lo enunció Menéndez Pelayo- que en el XIV, con don Juan Manuel y el Arcipreste, surgen ya grandes individualidades de estilo, de voluntad de estilo, y más tarde en el siguiente Cuatrocientos se intentan otros modos estilísticos: hay una poética característica de la centuria de ese Cuatrocientos. Incluso se ha interpretado que la oscuridad del segundo de tales siglos prolonga el intento parcial de oscuridad juanmanuelina:

El ingenuo alarde de oscuridad —manifiesta Menéndez Pidal— hecho tan insistentemente por los epígrafes de[1 Cancionero de Baena...] nos dice hasta qué punto estos poetas andaluces se empeñaron en dar cima al intento de difícil comprensibilidad, frustrado por inmaduro en manos de don Juan Manuel (lo que sigue ahora de don Ramón, en Menéndez Pidal, 2005, I, pp. 603; 605; 608-609; 610; 617-622 y 630).

Otro canon que se interpreta también que resultó actuante en el Cuatrocientos es el del mencionado Villena: «la prosa literaria, innovadora, trabajada y difícil como la poe- 
sía, se constituye por empeño principal de don Enrique de Villena [...] Fueron los Trabajos de Hércules y la Eneida los que dieron el modelo [...] en los 40 años siguientes». Estamos pues ante la poética específica del XV.

\section{Una nueva poética cultista y latinizante(II)}

La presente poética incluyó asimismo la mezcla en una composición de «el estilo complicado y el natural»: Mena, Santillana, ... Estamos de esta manera -e. gr.— ante el Claro escuro de Mena, una composición amorosa en la que uno de sus editores (Pérez Priego, 1983) subraya sus dos maneras de estilo: el uno claro y «sin grandes alardes ornamentales, y otro oscuro [...] basado particularmente en la dificultad docta que entrañaba el abrumador empleo de la alusión culta». En una de las estrofas claras y más fácilmente inteligibles, el poeta cordobés escribe:

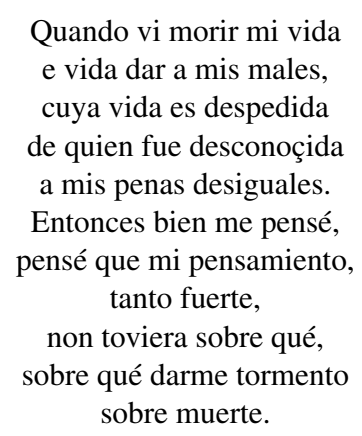

Observamos aquí las recurrencias; la derivación; Menéndez Pidal manifiesta bellamente cómo asistimos a «un balbuceo repetidor de palabras, propio de la lengua conversacional hablada con distraído afecto», tartajeo que luego asimismo se encontrará en poetas del siglo XX. Casi coherentemente — cabría decir- el poeta manifestará hacia el final de su composición cómo desestima la «poesía moderna» de su tiempo frente al impulso amoroso, a saber:

\footnotetext{
Non me conmueve la gran disciplina

de la poesía moderna abusiva, [...]

mas causa me mueve del daño que passo,

que fuerças y seso y bienes me priva.
}

Y en cuanto a temática, además de esto se ha observado que las letras bellas ya no tratan del orden estamental establecido, etc., tal como había hecho don Juan Manuel en el Libro de los estados - libro en cuyo título la palabra «estados» significa «estamentos»—, sino la crisis castellana bajomedieval y el desorden moral de los tiempos; por igual el maestro don Ramón alude discretamente asimismo, al gusto por traspasar las interdicciones lingüísticas presente en el Cancionero de Baena mediante pasajes obscenos (en efecto y por ej. este de Baena, debido a Álvarez de Villasandino: «Señora, pues que non puedo / abrevar el mi carajo / en esse vuestro lavajo / por demás es mi denuedo. [...]. Como el asno a la borrica / vos querría enamorar; / non vos ver, mas apalpar / yo desseo vuestra crica»). 
Desde los años finales de Alfonso X —en efecto-, ocurre un desorden moral en Castilla que se prolonga secularmente, y resulta un atrayente asunto de investigación.

Queda apuntado cómo el Cuatrocientos desestima para el arte verbal el idioma vernáculo; en referencia a las traducciones de Villena y de otros autores, el propio Menéndez Pidal comenta cómo «las dificultades de toda traducción fueron sentidas con desconsolador pesimismo sobre el valor estético de la lengua vulgar»; a toda costa y en general, los autores se inclinan por el retoricismo, y retórica en este Cuatrocientos quiere decir «latinización y mitología desbordantes», latinismo que no es de carácter práctico como el de dos siglos antes, sino que resulta «esencialmente de carácter estético», la estética verbal del siglo — claro es-.

La sintaxis resulta de esta manera artificiosa -posposición del verbo; oraciones de infinitivo; participios de presente; hipérbatos; la figura etimológica; ...

\section{En torno al marqués de Santillana}

Las centurias del XV y del XVI han sido las más abordadas por el filólogo Rafael Lapesa tanto en lo literario como en lo lingüístico (Santillana, Garcilaso, orígenes del andalucismo idiomático y del español en América, etc.); un grupo de sus aportaciones responden realmente al título que puso a uno de sus artículos: «Poesía de cancionero y poesía italianizante» —ya en 1947 había escrito sobre esto—- Lapesa ha ido apuntando algunos hechos de lengua y estilo acerca del Marqués, varios de los cuales resultan ilustrativos:

a) Repeticiones verbales fijas:

El triste que se despide, de plazer e de folgura se despide,

pues que su triste ventura

lo despide

de vos, linda creatura

(todos los textos de Santillana van según Gómez Moreno-Kerkhof, 1988).

b) Con el decir «Quando la fortuna quiso» — enseña don Rafael— entran en la poesía castellana «los «opósitos» de la lírica trovadoresca y del petrarquismo», e. gr.:

Deseo no dessear

y querría no querer;

de mi pesar he plazer

y de mi gozo pesar.

Lloro e río en un momento

e soy contento e quexoso,

ardid me fallo e medroso:[...].

c) El propósito de crear poesía sabia tiene como consecuencia inmediata el crecimiento del vocabulario latinizante» (para esto, Lapesa, 1957, pp. 82-83; 87; 162 168; y Lapesa, 1997, pp. 82-84).

d) En la lírica de Santillana «lugar preferido para el hiato suele ser entre las dos palabras separadas por la cesura, que de este modo escinde el endecasílabo en forma desusada para nosotros: [...] 


\section{El agua blanda / en la peña dura.}

Añádase la acumulación de acentos en sílabas seguidas, causa de la dureza con que suenan no pocos versos; la abundancia de rimas agudas», etc. (Lapesa, 1957, p. 195, y sobre «el arte de la prosa en Santillana», pp. 257-260).

De la misma manera que a Santillana, Lapesa se refiere en algunos de los trabajos de ya su tercera edad a la poética general del Cuatrocientos:

e) «La poética del arte de cancionero [se halló] vigente en el siglo y medio que va desde los primeros trastámaras hasta la época de Carlos V».

f) En un momento de la centuria del XV, «las coplas de arte mayor, tan favorecidas [Baena, Comedieta de Ponza, Laberinto de Fortuna], seguían usándose en la poesía de gran aparato; pero perdían terreno ante el empuje del octosílabo y las coplas de pie quebrado»: Gómez Manrique; Jorge Manrique; Juan del Enzina.

g) Manifestación poética es el subgénero de los disparates, consistentes en enunciados «cuya perfecta congruencia sintáctica choca con la absoluta incongruencia léxico-semántica».

h) En tanto conclusión, Rafael Lapesa manifiesta que «a pesar de que a primera vista la poesía cancioneresca nos parezca hoy uniforme y monótona, venía renovándose gracias a la creciente penetración del humanismo [...]; por eso no se había reducido a frivolidades cortesanas y conceptismo vacío. [...] Una nueva sensibilidad y una nueva actitud vital se abrían camino» (Lapesa, 1997, pp. 123; 125-126; 137; 138).

\section{Etapas hacia la poética del Quinientos: de los estilos B a los A}

De manera muy diferente respecto de los estilos y la lengua materna vernácula se manifestará avanzado ya el siglo XV, en torno a 1475, Pero Guillén de Segovia en su Libro de los consonantes o Gaya ciencia; se manifiesta el texto en favor de la lengua romance, el designio de una elocución que no sea ya un discurrir latinizante: «Porque commo dixe, avnque desta çiençia gaya aya aujdo muchos y prudentes actores, paresçe que todos aquellos que della fablaron la pusieron en el latyn y en estilo tanto eleuado que pocos de los lectores pueden sacar verdaderas sentençias de sus dychos, quise yo [...] escreuir algo dello en el rromançe, so estilo baxo y omilde» (Casas, 1962, I, p. 43). Nada importa — viene a decir el autor- la expresión en estilo humilde si con ello se alcanza la comprensión de lo que se manifiesta: puede prescindirse del estilo elevado y en latín, si es que no aprovecha a los lectores; el idioma latino no aparece ya en tanto un canon de la elocución, sino que se estima sobre todo la lengua que nos es natural: importa el romance comprensible, aunque esto suponga expresarse en bajo estilo. Pero Guillén avalora el romance como medio de claridad en la exposición elocutiva.

La poética de la oscuridad comparece ya en este Cuatrocientos-de la misma manera que había comparecido en un momento de particular relieve literario: el segundo cuarto del siglo XIV—, otra vez en el Cancionero de Baena, lo que se percibe en sus epígrafes, por ej.: «Este dezir fizo e ordenó el dicho Gonçalo Martínez de Medina, fablando por metáforas obscuras en las personas divinas que son en la Trinidat, [...]»; en esta composición se emplea además el superlativo hebraico: «La lumbre de lumbre, la lumbre inmutante / e Dios de Dios»; etc. (Dutton, 1993, pp. 594-598). Otro dezir del mismo Cancionero de 
Baena lo «fizo e ordenó el dicho Maestro Frey Lope del Monte por manera de metáforas oscuras e muy secretas»(Ibid., pp. 623-625). Etc. Menéndez Pidal creyó que los poetas del presente Cancionero... «se empeñaron en dar cima al intento de difícil comprensibilidad, frustrado por inmaduro en manos de don Juan Manuel» (2005, I, p. 603); debe interpretarse no obstante - a diferencia del maestro- que estamos en realidad ante otro modo de poética, que simplemente posee un punto de contacto con la juanmanuelina.

En el mismo Baena no pasan inadvertidos los juegos poéticos con rimas obligadas: se trataba de consonantes forzados, y veremos cómo en la misma centuria del XV y luego en el XVI Nebrija o Garcilaso —en la práctica — postulaban una poética opuesta y que no se valga como recurso fundamental del consonante (se pasa — digamos- de una manera de estilo B que tiende a artificioso a otra manera de estilo A que tiende a clasicista): hay un «Dezir» de Ferrant Manuel de Lando con cerca de cien consonantes en -al (los contó don Ramón, y los hemos vuelto a contar nosotros), y naturalmente con latinismos («sala presençial», etc.; Dutton, pp. 484-489); otras composiciones hacen empleo de los consonantes en -ique y enhebran así voces «desconocidas poco menos que hoy»: idea de algunos de estos juegos poéticos frívolos se encuentran por ej. en una «Respuesta de Ferrand Manuel contra Juan Alfonso» — añadimos entre corchetes algunas aclaraciones léxicas tal como las dan Dutton y Gonz. Cuenca-: «Maguer vos andades acá por la villa, / a vuestra muger bien ay quien la nique ["fornique"] / [...] por ende, sed çierto, si a mí me lo empresta, / que juegos le fago con el çiquezique [“carajo"]» (Menéndez Pidal, 2005, I, pp. 604; Dutton, p. 641; ...).

El mismo don Ramón advirtió en Gómez Manrique el hipérbaton cuatrocentista, la figura etimológica («con muchas dubdas dubdoso»), etc., pero cree percibir ya en por ej. la tardía Consolatoria a su mujer doña Juana de Mendoza la muestra de «una hermosa lengua de naturalidad [...] que anuncia el lenguaje del siglo XVI»; además en líneas generales y salvo algunos matices, cabe aceptar la percepción pidalina referida respectivamente a Santillana, a Gómez Manrique y a Jorge Manrique, de que «en tres generaciones de esta noble familia Mendoza-Manrique se personifican el auge del estilo retórico, su transición[,] y el comienzo de un nuevo tipo de lengua literaria» (2005, I, 635-636).

Se da también en la historia de los estilos de arte verbal un cansancio de las formas, según estableció en las décadas primeras del siglo XX la historiografía del Arte, y asimiló Menéndez Pidal, y podemos establecer de esta manera cómo en general la poética más característica cuatrocentrista resulta distinta a las que la anteceden en la serie literaria castellana, y a la vez a ella se opone la poética más característica del Quinientos hasta bien avanzada la centuria. A un modo de invención, disposición y elocución, sucede en la serie literaria otro: es la sucesión de las formas. Garcilaso escribirá en contra de como había escrito Juan de Mena, y en contra de la serie castellana tradicional en poesía.

Aunque sea de manera informal e intuitiva, contrástese la diferencia a favor de Garcilaso que hay entre su lírica amorosa, y por ej. estos dos fragmentos anteriores de Juan de Mena:

\footnotetext{
Más clara que non la luna sola una

en el mundo vos naçistes, tan gentil que non ovistes nin tovistes
} 


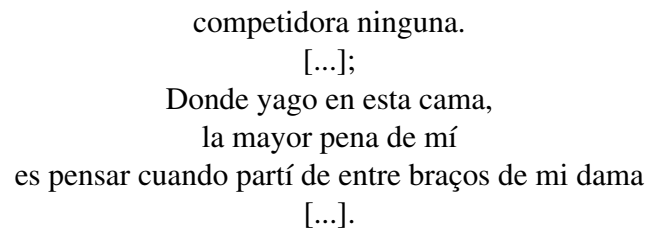

A propósito de Mena, J. L. Alborg creemos no acierta cuando califica la poesía de este autor de «gran sentido musical» (Alborg, 1970, pp. 365-366): justamente ocurre lo contrario, es muy rítmica - tal como vieron ya nuestros tratadistas de los siglos de oro-, pero nada musical si entendemos por musical que resulta "melodiosa».

Don Dámaso no obstante ha estimado su logro de «sac[ar] los mayores frutos que entonces se podían obtener del verso [...] de arte mayor [...] matizándolo y aumentando su poder de expresión»; en cuanto a la introducción de latinismos en el discurso, el crítico interpreta cómo Mena, por ambición literaria épica, «necesitaba enriquecer el castellano para tener una lengua digna de cantar grandes acciones (por eso introdujo tantas voces latinas)» (D. Alonso, 1942, p. 551): el designio de estilo resulta así concomitante con el cultismo léxico latinista.

\section{Comentarios bibliográficos}

De don Ramón ha de verse también ahora —además de su necesaria Historia de la lengua española - el artículo antecedente de 1933 ya mencionado; reiteramos la respectiva ficha: R. Menéndez Pidal, «El lenguaje del siglo XVI», Cruz y Raya, 6, 15 de Septiembre, 1933, pp. 7-63; Historia de la lengua española, Madrid, Fundación Ramón Menéndez Pidal y Real Academia Española, 2005, I y II.

La obra mencionada de C. Gariano incluye un capítulo de usos estilísticos.

La referencia a un libro de don Dámaso es a su bella Antologías de la poesía española. Poesía de la Edad Media y poesía de tipo tradicional; esta segunda edición del libro, estuvo al cuidado de Amado Alonso.

Por supuesto sobre Mena y sobre la centuria es indispensable el libro que dedicó al poeta $\mathrm{M}^{\mathrm{a}}$ Rosa Lida.

La monografía de R. Lapesa La obra literaria del marqués de Santillana, está vigente y resulta de lectura necesaria más de medio siglo después de quedar publicada. El otro volumen mencionado del mismo estudioso, De Berceo a Jorge Guillén, incluye sucesivas páginas sobre Santillana y el siglo XV.

El comentario de texto de Pérez Priego sobre el «Claro escuro», se halla en el volumen colectivo El comentario de textos, 4. La poesía medieval, el cual contiene otros comentarios - no todos bien logrados- pertinentes.

\section{Palabras y CONCEPTOS}

1. Conceptos y palabras en Dámaso Alonso: gongorismo, conceptismo, barroco, etc.

En lo que se refiere a los estilos del Renacimiento y más en particular del Barroco, y en particular a Góngora, tiene entre nosotros destacado relieve la obra de dos estudio- 
sos: nos referimos (como seguramente se habrá adivinado) a Dámaso Alonso y a Emilio Orozco, aunque no siempre cabe seguirles; por edad acaso empleó antes varios conceptos y lexías [«unidad léxica»] don Dámaso, aunque no siempre es fácil estar completamente seguros de esto.

Dámaso Alonso propuso una terminología específica para referirse a los estilos cualitativamente distintos de los siglos XVI y XVII: estamos ante conceptos y ante voces o palabras.

Nuestro autor pone de relieve el contraste entre la sencillez quinientista y la complicación seiscentista, y se manifiesta así, de manera simplificada y abreviada:

Cualquiera que compare un poema de Garcilaso [...] con uno de Góngora [...] notará un abismo entre uno y otro autor, es decir, entre fines del primer tercio del siglo XVI y el primer tercio del XVII. [... Si acudimos ahora a la prosa] veríamos también una inmensa diferencia: hay en la prosa de Quevedo una abundancia de sutilezas y rebuscamientos de múltiples clases, que no aparecen —o escasísimamente- en el Lazarillo. [...] Estas diferencias entre el siglo XVI y el XVII [...] parece que lo mismo en poesía que en prosa son diferencias entre una sencillez más o menos relativa, en el siglo XVI, y una evidente complicación en el XVII. [ «Resulta pues que tanto el gongorismo como el conceptismo»] son modas literarias que existían en el siglo XVII y que el uno y el otro eran estilos mucho más complicados (y por tanto difíciles) que el predominante en la poesía y la prosa del siglo XVI.

Don Dámaso efectivamente contrasta las centurias del XVI y del XVII, contrasta los que — si se acepta así - podemos llamar modos de estilo A y B, y emplea en su vocabulario las voces sencillez, complicación, gongorismo, conceptismo, o estilos difíciles $(=«$ dificultad»).

Las lexías culteranismo y cultismo literario resultan asimismo empleadas y explicadas por Dámaso Alonso. A propósito del culteranismo recuerda cómo el gongorismo suele ser llamado también

cultismo, y con un matiz despectivo, culteranismo, palabra esta última inventada en la época de Góngora por un erudito llamado Jiménez Patón (que era un gran admirador de Lope): hay que notar que culteranismo es una palabra formada recordando a luteranismo. El gongorismo quedaba percibido en tanto una herejía porque iba en efecto en contra del clasicismo seiscentista, era un modo de estilo que se oponía y confrontaba con otra manera estilística en el arte verbal.

Y nuestro autor aclara aún la idea que expresa la fórmula verbal cultismo literario, y vuelve a definir en ese contexto qué es el gongorismo, a saber:

La corriente culta en literatura [...] tiene como norma general la imitación de los escritores de la antigüedad grecolatina: imitación en los géneros ( a esto se debe la boga del pastoril, de Garcilaso a Góngora), en los temas [...]; pero imitación también en el léxico (y a esto se debe la inundación de voces cultas, o «cultismos léxicos»), y lo mismo imitación en la sintaxis, [etc. ...] El gongorismo es pues una manifestación particular del cultismo literario prevalente y creciente en España (y en Italia y gran parte de Europa) en el siglo XVI y el XVII.

En la tradición del cultismo literario, se inserta por tanto como una de sus manifestaciones el gongorismo, y ambos hechos no deberán identificarse sin más. 
Además habla don Dámaso de la generalización — «ya avanzada la primera mitad del siglo $[\mathrm{XX}]$ en que vivimos»- del término barroquismo, y sintetiza lo que cabe saber del término Barroco; nuestro crítico escribe este amplio párrafo:

Baroco era uno de los tipos escolásticos de silogismo (recuérdese la retahíla Barbara, Celarent, etc.). El término fue ridiculizado a veces por los escritores renacentistas (Luis Vives habla de filósofo en baroco y baralipton). Por otra parte, hay la palabra portuguesa barroco «barrueco, perla de superficie irregular». Probablemente las dos procedencias se confundieron en el francés baroque, que ya en el siglo XVIII toma un sentido de «extravagante». Burckhardt parece ser quien naturalizó el vocablo en historia del arte al caracterizar lo que consideraba la decadencia de la arquitectura renacentista al llegar al adornado estilo de la época de la contrarreforma [...]. Wölfflin lleva la palabra al título de su libro Renacimiento y barroco, en 1888, y sugiere allí la posibilidad de extensión del concepto a otros dominios: a la literatura y a música. Wölfflin, al mismo tiempo había emprendido la revalorización del arte barroco, y tuvo pronto muchos seguidores. Después de la primera guerra mundial (1914-1918) el término se ha extendido a varios países. En España lo usa pronto por ejemplo Eugenio d'Ors. [...] La aplicación a la literatura, apuntada ya en Wölfflin, tuvo escaso uso hasta 1914. Un año después el mismo Wölfflin publicó un nuevo libro, Ideas fundamentales en la historia del arte, en donde se contrastan como tipos de estilo, Renacimiento y Barroco[...]. Hacia 1921 es cuando la idea de un barroco literario tiene enorme expansión, primero entre los historiadores alemanes.

En la extensísima obra escrita de Dámaso Alonso el presente pasaje posee relieve, e ilustra bien el empleo de la palabra barroco y su introducción en nuestra lengua; ha quedado según nuestra experiencia de lector acaso un tanto inadvertido, pero no deja de tener valor valor testimonial y concreta brillantez (más datos en otras lenguas sobre el vocablo trae Tapié, 1978, pp. 22-34; lo mismo en 1981, cap. I, quien recoge la aguda percepción hecha por Burckhardt, de que la arquitectura barroca «habla la misma lengua que el Renacimiento, pero la ha convertido en un dialecto salvaje». De su obra de 1978, vid. también pp. 41-69).

Hemos de decir por igual que a veces la crítica emplea estas voces barroquismo y $B(b)$ arroco en tanto sinónimas. Pero en concreto don Dámaso desestima el empleo genérico aplicable a cualquier época del término $B(b)$ arroco, y lo avalora en tanto 'modo nacional y particular de un gusto' y aun 'un movimiento espiritual general a gran parte de Europa, que [...] tuvo sus manifestaciones más evidentes en el siglo XVII'. Estamos pues ante un concepto de época, ante un conjunto situacional de rasgos históricos, y en este sentido de época delimitado cronológica y espacial o subespacialmente (Italia, Francia, España, etc.) reivindica emplearlo D. Alonso, y lo empleará asimismo E. Orozco.

En fin y en sus páginas presentes el poeta y crítico madrileño establece por igual cómo el conceptismo se halla también en el gongorismo, es decir, que «en el fondo del gongorismo hay siempre una tendencia que tenemos que llamar conceptista. [...] Hay un conceptismo también en la base del gongorismo.[...] Tanto el gongorismo como el puro conceptismo son técnicas formalistas».

Dámaso Alonso analiza y define por último el barroquismo del XVII español en gongorismo ( «recargamiento ornamental y sensorial, entrelazado con una complicación conceptista»), y lo que llama conceptismo o conceptismo puro («complicación conceptual obtenida en parte por procedimientos no desemejantes de los del gongorismo, pero sin el recargamiento ornamental y sensorial de éste»), conceptos que en muchas 
ocasiones no son sino ingeniosidades (todos los pasajes recogidos en D. Alonso, 1984, pp.80-90; se corresponden en lo que respecta al léxico con la lengua española del segundo tercio del siglo XX).

\section{Conceptos y palabras en Emilio Orozco: gongorismo, conceptismo, barroco, manierismo, etc.}

En nuestra crítica y tras el biógrafo de Góngora don Miguel Artigas, sobresale junto al estudioso madrileño a quien acabamos de ver, el profesor granadino Emilio Orozco, quien empezó a tratar de estas cuestiones desde la guerra civil: ya en las primeras líneas de su obra Pedro Atanasio Bocanegra (1937) alude a «el arte barroco» y a «la rehabilitación del barroco» que estaba ocurriendo en aquellos años. La voz barroco vemos la emplea con naturalidad el autor desde sus inicios; el concepto y la voz, más otros conceptos y voces concomitantes, vamos a verlos por igual en algunos de sus textos posteriores, y los veremos según la cronología de su primera publicación respectiva.

En el conjunto también del idioma del segundo tercio de la centuria del XX Emilio Orozco emplea con naturalidad y estandarización las palabras barroquismo y Barroco, parece hacerlas equivaler en cuanto sinónimos, y señala como rasgos del estilo «agitación y retorcimiento de sus elementos constructivos; alteración de éstos en sus funciones; desbordamiento de lo ornamental, que rotos sus cauces, lo invade todo dificultando y ocultando la trama o construcción logicoargumental, apenas visible tras el brillo, color y musicalidad del verso». Por supuesto emplea a la vez la voz culterano: todos estos conceptos y sus correspondientes palabras se hallaban completamente naturalizadas entre los estudiosos, y así Orozco escribe al igual que D. Alonso - no sabemos si antes o después que él一:

Sería erróneo suponer que el barroquismo en la poesía o concretamente el movimiento culterano, es un fenómeno que no se produce hasta Góngora, que sería así su iniciador y único determinante. Esto sería olvidar que el poeta está dentro de un movimiento general cultista [...]. Si pensamos en que antes de que el gran cordobés provocara la polémica en torno a las Soledades, ya el culteranismo era cuestión discutida, [...] comprenderemos mejor la necesidad de no identificar culteranismo y gongorismo. [...] Dentro del movimiento culterano el gongorismo fue la más cabal y alta expresión de lo barroco en nuestras letras.

Vemos así al crítico operar con las palabras e ideas de B(b)arroco, culteranismo, o gongorismo (Orozco, 1953, pp. 13-15).

La garcilasiana fue una revolución en la poética, y de la misma manera emplea nuestro autor la fórmula verbal «revolución poética» para referirse a la llevada a cabo por Góngora, revolución que entre otras cosas se encontraba en lo que comentó el Abad de Rute acerca de que un poema lírico podía resultar extenso y con acciones diversas, y que aunque esto lo hubiesen admitido los «antiguos», «para sus tiempos pudo correr; ya corren otros, y otros gustos», esto es, vemos apelarse al gusto de los tiempos, o sea, de los modernos; el presente comentarista de don Luis pierde el respeto a los «antiguos» al igual que don Luis y que Lope, y tal es el fundamento de la nueva lírica y la nueva tragicomedia (Ibid., pp. 19 y 22-23). 
Por lo demás y en estos momentos de los cincuenta, nuestro autor sugiere «unos años», una segunda época, en la poesía de don Luis (Ibid., p. 55).

A Dámaso Alonso le importaban más los asuntos filológicos, mientras Emilio Orozco se interesaba también por las cuestiones estéticas, y de esta manera introdujo en sus textos la idea, la definición y la palabra Manierismo.

El Manierismo - escribe por ej.— «se produce por un exceso de intelectualismo e individualismo, es decir, por una búsqueda de nuevas y extrañas formas de belleza. Cuando Herrera declara que hay que buscar con el entendimiento nuevos modos de expresión, está afirmando una postura manierista. Sus teorizantes no admiten la imitación directa de la realidad, sino a través de la imitación de los antiguos poetas y artistas. [...] Hay una postura intelectual, esteticista y técnica en su orientación que les hará buscar la consciente complicación, la dificultad por la dificultad, esto es, el acomodamiento de la expresión artística o poética a esquemas compositivos previos; lo mismo la complejidad temática que el artificio estilístico. [... El manierista] ve la obra de arte como fruto del saber y de la idea y no del impulso natural y de la práctica».

Manierismo, manierista en su empleo sustantivo o adjetivo, complicación, complejidad, resultan palabras empleadas por el crítico como consecuencia de su uso de una específica conceptuación acerca de los estilos.

Abundando en lo mismo, la lexía complicación manierista aparece también directamente: «La complejidad y complicación manierista [...] es impuesta en un exceso de formalismo como molde o esquema» (para lo anterior Orozco, 1981, pp. 161 y 166).

Poco después insiste nuestro autor en el «sentido anticlásico» de los estilos manierista y barroco, y ensaya una delimitación de ellos, dándoles su respectivo nombre:

El Manierismo ofrece como determinante una actitud intelectualista, ultraconsciente, del poeta y del artista que como tal artista —y no en general como hombre- busca la expresión de lo nuevo, forzadamente complicado y sorprendente, que en lo esencial tiende a actuar sobre el intelecto; pero el estilo barroco se mueve por íntimos impulsos de espíritu y vida, complica con espontánea violencia las formas, y sobrevalora y recarga el elemento ornamental y aparencial procurando actuar intensa y directamente sobre los sentidos.

Un estilo supone por tanto lo intelectualista, una emoción artística racional; el otro implica la emoción sensorial y vital, el Manierismo busca así «lo abstracto, ideal y dibujístico»; el Barroco tiende «a lo sensorial colorista, luminoso e irracional» (Orozco, 1969, pp. 18-19; en esta obra Orozco se refiere entre otras cosas a lo barroco del teatro clasicista francés; para ello vid. con anterioridad V.-L. Tapié; 1981, pp. 24-41 y 85-106, para quien «las afinidades barrocas [...] no dejan de ser numerosas en el clasicismo francés», y quien asimismo subraya «la voluntad de ejecutar lo raro» del Manierismo. Desde luego vid. también V.-L. Tapié, 1978).

En años posteriores (1975), E. Orozco publicó un logrado e importante estudio de título dado por la editorial: «Características generales del siglo XVII», que realmente es una *Introducción al Barroco literario español, tal como se ha reeditado póstumamente. El autor dedica uno de sus capitulillos a «El Barroco: el término y el concepto»: alude a las acepciones primigenias que ya sabemos de "perla de forma irregular» y de «fórmula silogística ridícula», así como a otra de "término jurídico de la Toscana», y concluye con que si se consideran tales tres posibles orígenes «descúbrense aspectos del fenómeno 
estilístico barroco, ya en lo propiamente morfológico ya en lo conceptual e ideológico, y siempre con el sentido despectivo que ha perdurado en la mayor parte de la crítica hasta muy avanzado nuestro siglo [XX], y que aún se conserva en parte en parte en el hablar cotidiano». Y desarrolla con brillantez y aclara más nuestro autor:

Es claro que la perla, con sus brillos irisados y con la superficie abultada irregular que rompe la perfección equilibrada de la esfera, sugiere tensión dinámica, cambiante efecto visual y extrañeza de forma, acorde con la belleza sensorial sorprendente y rara de lo que estimamos típico [...] de la obra barroca. Por otra parte la convencional y complicada fórmula silogística es expresiva del hábil juego de ingenio, de proceso intelectual inútil [...]. Así la valoración de lo sensorial brillante y dinámico de las formas - típico de lo barroco y acorde con la tendencia que extrema el cultismo gongorino-, y por otra parte la ingeniosidad y extrañeza del juego intelectual característico de la actitud y expresión conceptista, se aviene bien con aspectos esenciales del barroquismo [...].Incluso la acepción etimológica jurídica referida a lo engañoso y capcioso, se puede asociar a los efectismos y engaños de la vida y de la expresión, típicos del extremismo barroco (para esto y lo siguiente Orozco, 1988, I, pp. 27-33; 49-50; $60-61 ; 114 ; 203-245)$.

La crítica por tanto ha encontrado motivos para postular uno u otro origen de la voz barroco, voz que E. Orozco — de acuerdo con una percepción anterior de Francisco Javier Sánchez Cantón — estima que «no aparece hasta bien entrada la segunda mitad del siglo XIX»; entre nosotros (añade) se dijo asimismo churrigueresco y churriguerismo.

El propio E. Orozco concreta asimismo cómo hacia fines del Ochocientos la palabra barroco se va extendiendo en la historiografía del arte en España, mas «se mantiene en general la preferencia por el término churrigueresco, por dársele a éste una significación más acentuadamente peyorativa»; también nuestro crítico destaca que fue el novelista Pedro Antonio de Alarcón quien entre los escritores emplea con reiteración ese término barroco con una connotación ya de cierto aprecio por el estilo.

Establece el estudioso granadino una sugerente analogía entre la historia de los estilos en tanto historia de las formas (Barroco vs. Renacimiento), y la lingüística idealista frente a la meramente positivista; escribe en particular: «Esta consideración de la evolución de las formas clásicas renacentistas no debe detenerse en la pura abstracción del formalismo [...]. Resultaría análog[o] a lo que se daba en la consideración positivista del lenguaje cuando se lo estimaba como una realidad independiente, con vida propia, regido por sus leyes; olvidando que junto a la transmisión del lenguaje como convención hay una parte creadora del individuo». Ciertamente la historia idiomática o gramática histórica tal como la planteaba el positivismo estricto era una historia inmanente de formas, y de la misma manera la historia sólo formal de los estilos resulta una historia inmanente: E. Orozco viene a decir que cabe completarlas con una historia del espíritu en ambos casos.

Otra advertencia de nuestro autor es la de que el concepto y la palabra gongorismo hacen referencia a algo «más específico del estilo del poeta, que se realiza plenamente en su segunda época y que lleva implícito como uno de sus rasgos importantes el conceptismo»; en fin emplea los conceptos y las voces manierismo y barroco, y caracteriza con acierto y sintéticamente: «Se trata pues de dos concepciones de fondo anticlásico por su complejidad y complicación: predominantemente intelectualista y estética en el Manierismo, y vital y sensorial en el Barroco, y cuyo sistema o principio estructural responde en el primer caso a la composición [...] y en el segundo a la mezcla». Anticlásico, 
anticlasicismo, son vocablos y conceptos que han de surgir necesariamente cuando se trata de los estilos Manierista y Barroco.

\section{Apuntes sobre «churrigueresco»}

Entre nosotros se acuñó y empleó efectivamente — según advertía Orozco— esta voz churrigueresco, sobre la que cabe ver algo de su trayectoria.

Estamos ante un adjetivo que se halla presente ya en el $D R A E$ de 1852 , adjetivo — se nos dice- que «se aplica al gusto introducido en la arquitectura en España por Churriguera, Ribera y sus secuaces en los primeros años del siglo XVIII»; la definición se repite en la edición del Diccionario de 1869, mientras en la de 1884 encontramos dos acepciones: la una enuncia «dícese del gusto introducido en la arquitectura española por Churriguera, Ribera y sus secuaces en los primeros años del siglo XVIII»; la otra remite a una de las acepciones de charro, la de «aplícase á algunas cosas demasiadamente cargadas de adorno, y de mal gusto».

No aparecen novedades en los siete léxicos académicos que van hasta mitad de la centuria del XX; el Diccionario manual de 1950 hace del presente significado de charro —en la entrada churrigueresco- simplemente «de mal gusto, recargado», mientras en la entrada charro se lee otra vez: «aplícase a algunas cosas demasiadamente cargadas de adorno, y de mal gusto».

Llegamos al DRAE del año 1970, en el que registramos una innovación: la voz churrigueresco enuncia: "perteneciente o relativo al churriguerismo», y esta palabra churriguerismo significa «estilo de ornamentación recargada empleado por Churriguera y sus imitadores en la arquitectura española del siglo XVIII. Por ext., denota a veces en sent. despect., la ornamentación exagerada en general». Las versiones del Diccionario -el común o el manual— de 1983, 1984, 1989 y 1992 mantienen el estado de cosas, y en 2001 se precisa más lo enciclopédico; leemos en churriguerismo «estilo de ornamentación recargada empleado por Churriguera, arquitecto y escultor barroco de fines del siglo XVII, y sus imitadores en la arquitectura española del siglo XVIII»; "ornamentación exagerada» —en registro despectivo-.

Digamos en fin que el excelente DEA escribe en la entrada churrigueresco: «[estilo] del arquitecto José de Churriguera (†1725), cuya característica principal es la exhuberancia decorativa»; «[cosa] recargada o excesivamente ornamentada».

\section{EI Barroco en tanto concepto de época}

La voz barroco posee asimismo en la literatura técnica otra acepción que es la de 'modo o estructura de vida', y es la que tiene en el bello libro de José Antonio Maravall La cultura del Barroco; el libro se edita en 1975, y en el inmediatamente anterior DRAE del año 70 la voz no tiene aún esta acepción, aunque estaba ya bien vigente: había escapado a la atención académica.

De acuerdo con su principio historiográfico — expuesto en otras obras — de entender las épocas del pasado como «conjuntos situacionales» que a veces conocemos con el nombre de sus estilos —o los estilos con el nombre de la época, pues a veces esto 
parece inescindible- («Gótico», «Renacimiento», «Barroco», «Romanticismo», ...), Maravall se opone a considerar lo barroco en tanto una "constante estilística» o "fase final de un estilo», para considerar que la palabra designa un concepto de época, a saber: «El Barroco ha dejado de ser para nosotros un concepto de estilo que pueda repetirse y que de hecho se supone se ha repetido en múltiples fases de la historia humana; ha venido a ser, en franca contradicción con lo anterior, un mero concepto de época»; esta época barroca se delimita así entre nosotros «desde 1600 aproximadamente (sin perjuicio de que ciertos fenómenos de precoz significación barroca se anuncien años antes [...], hasta 1670-1680 (cambio de coyuntura económica y primeros ecos de la ciencia moderna)», esto es, en los tres primeros cuartos del Seiscientos, y «con mayor intensidad [...] de 1605 a 1650). Estamos por tanto ante la idea de una época, ante un concepto «que se extiende en principio a todas las manifestaciones que se integran en la cultura de la misma».

Subraya naturalmente Maravall cómo «es a una de esas irrepetibles realidades (tal como se combinaron una serie de factores en el siglo XVII) a la que llamamos Barroco»: se trata de una situación de época delimitable y distinguible en lo histórico, y a ella se la designa con el vocablo barroco; de esta manera «son razones [...] de situación histórica, las que hicieron surgir la cultura barroca. Tenemos así —y esto lo define el $D E A$ - que nuestro Barroco es una cultura, cultura entendida en tanto "conjunto de modos de vida, conocimientos y grado de desarrollo de una colectividad humana o de una época».

En fin cabe recoger unas estimulantes palabras de José Antonio Maravall acerca de la revalorización sobre esta época y estilo en los estudios, y que dicen: «Se ha incorporado al estudio del Barroco europeo la rica región del XVII español. El redescubrimiento del Greco, la creciente admiración por Velázquez, Zurbarán, Ribera, etc., la estimación del teatro, de la novela picaresca e incluso de la poesía lírica, siempre más trivial, y finalmente la del pensamiento político y económico, han preparado el amplio desarrollo del estudio del Barroco español» (los pasajes citados en Maravall, 1975, pp. 23; 24 y 29; 34 y 46; 39).

Barroco aparece en tanto «designando época» en el DEA.

\section{Comentarios bibliográficos}

De los libros de Orozco, su Góngora estaba escrito ya para 1950; la Introducción a Góngora posterior consiste en la reedición de esa primitiva monografía de 1953 dedicada al poeta, más unas amplias notas adicionales que ponen su planteamiento a la altura de los años ochenta en que luego escribe.

Del conjunto de artículos que dan lugar a Manierismo y Barroco, importa sobre todo ahora el dedicado justamente a la caracterización de ambos estilos en poesía, con ejemplos de sonetos de Góngora; de la religiosidad y expresión artística de Miguel Ángel trata un capítulo de su volumen Mística, plástica y Barroco.

Los dos volúmenes de Introducción al Barroco son muy maduros y logrados: la extensa exposición de inicio se acerca mucho a lo magistral.

Por supuesto el número de los gongoristas —más de uno de notoria excelencia, como A. Carreira y A. de Paz, M. Blanco, etc.— ha continuado luego. 
BibliogRAfía DE LAS NOTAS I y II (se alude asimismo a alguno más en la Bibliografía de esas notas)

Alborg, JuAn Luis (1970). Historia de la literatura española. I., Madrid, Gredos, segunda ed. ampliada.

Alonso, Dámaso (1942). Antologías de la poesía española. Poesía de la Edad Media y poesía de tipo tradicional, Buenos Aires, Losada.

Alonso, D. (1984): Obras Completas. VII, Madrid, Gredos.

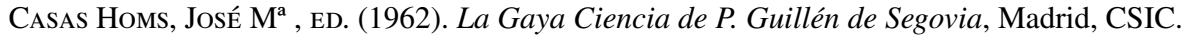

Dutton, Brian y González Cuenca, eds. (1993). Cancionero de Juan Alfonso de Baena, Madrid, Visor Libros.

Gariano, Carmelo (i974). El mundo poético de Juan Ruiz, Madrid, Gredos.

LAPESA, RAFAel (1957). La obra literaria del marqués de Santillana, Madrid, Ínsula.

- (I997). De Berceo a Jorge Guillén, Madrid, Gredos.

López de Mendoza, Íñigo, Marqués de Santillana (i988). Obras Completas, ed. de M. Kerkhof y A. Gómez Moreno, Barcelona, Planeta.

Maravall, José Antonio (i976). La cultura del Barroco, Barcelona, Ariel.

Mena, Juan de (1989). Obras Completas, ed. de M. A. Pérez Priego, Barcelona,Planeta.

Menéndez Pidal, Ramón (I933). «El lenguaje del siglo XVI», Cruz y Raya, 6, 15 de Septiembre, pp. 7-63.

Menéndez Pidal, Ramón (2005). Historia de la lengua española, Madrid, Fundación Ramón Menéndez Pidal y Real Academia Española, I y II.

Oliver Asín, Jaime (I940). Historia de la lengva española, cuarta edición, Madrid, Diana, Artes gráficas.

Orozco, Emilio (1953). Góngora, Barcelona, Labor.

- (I969). El teatro y la teatralidad del Barroco, Barcelona, Planeta.

- (1977). Mística, plástica y Barroco, Madrid, Cupsa.

- (I98I). Manierismo y Barroco, Madrid, Cátedra, tercera ed.

- (I988). Introducción al Barroco, Universidad de Granada, I y II.

Pérez Priego, Miguel Á. (1983). «El «Claro escuro» de Juan de Mena», en el vol colectivo El comentario de textos, 4. La poesía medieval, Madrid, Castalia, pp. 427-449.

SAntiago, RAmón, ed. y estudio (1979). Enrique de Villena, La primera versión castellana de «La Eneida», de Virgilio, Madrid, RAE.

TAPIÉ, V.-L. (1978). Barroco y Clasicismo, Madrid, Cátedra.

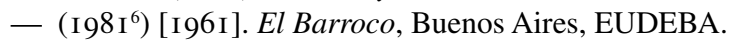

\section{LAS Historias DE LA LENGUA DE LAPESA}

Rafael Lapesa se refirió una vez a su propia Historia de la lengua, y en efecto cabe referirse a la trayectoria interna de esa obra imprescindible de aproximadamente la segunda mitad del siglo XX, y que continúa vigente en estos lustros primeros de nuestra centuria. Por nuestra parte vamos a referirnos a las dos primeras ediciones del texto; no tenemos a la vista la interpretación que hizo el propio don Rafael —aunque la hemos leído y tenemos algún recuerdo de ella-, pues no queremos repetirle sin más.

Américo Castro publicó en el año 1948 su obra España en su historia. Cristianos, moros y judíos, y nuestro autor la reseñó en la NRFH (III, 1949) que a su vez editaba entonces en Buenos Aires otro estudioso de la escuela pidalina: Amado Alonso. 
En esa reseña Lapesa daba cuenta ya de las «seudomorfosis», «esto es, formaciones que con aspecto exterior románico encierran un contenido sólo explicable por la presencia soterraña de formas expresivas y vitales árabes»: la obra de don Américo dejó huella en Lapesa y se adhirió en lo fundamental a ella, no obstante los «excesos» y «reparos» que le señalaba.

El autor valenciano mantuvo a lo largo de su vida esa postura. De su parte Jaume Vicens señaló en don Américo la falla principal de simplificar las geografías, cronologías y factores actuantes en el pasado español, que resulta sin duda harto más complejo.

Tenemos así cómo el entonces joven Rafael Lapesa preparó la segunda edición de su Historia de la lengua española tras haber conocido la España en su historia de don Américo, y de esta manera lo tuvo en cuenta; según se sabe la edición inicial de la Historia de la lengua... había aparecido ya en 1942, la posterior es de 1950, y el autor pudo prepararla en bibliotecas norteamericanas en las que enseñaba por entonces.

Una cala en la primera y segunda ediciones de la Historia... (1942/1950, Ed. Escelicer) nos lleva a proponer estas observaciones:

1. «España» se torna en «Hispania» al hacer referencia a Roma en la Península, de acuerdo con que no hay españoles antes del año 1000 (33/44 —indicamos desde ahora con la primera de estas cifras la página de la primera edición del libro de Lapesa, y con la segunda la página de la segunda edición-).

2. En las mismas páginas indicadas, se suprime en esta segunda ed. lo de que en las obras de Séneca, Lucano, o Marcial, «habla el alma española, aun sirviéndose de una lengua que acababa de adoptar». España resulta posterior al mencionado año Mil (A. Castro).

3. La segunda edición (78-79/96-97) se hace cargo ya de las nuevas investigaciones que sobre el mozárabe publicaba el benemérito Arnald Steiger.

4. De la misma manera se tienen en cuenta las averiguaciones de historia de la pronunciación de Amado Alonso: vid. la distinta redacción del pasaje acerca de s > $\check{\text { s }}(86 / 106)$.

5. La segunda ed. añade — de acuerdo con el texto mencionado de A. Castro y reseñado por Lapesa- el epígrafe «Arabismo semántico, sintáctico y fraseológico» (pp. 108-109).

6. Se atribuye a Menéndez Pidal según es usual (108/136) la imagen de la «cuña castellana», pero antes de don Ramón hizo uso de ella Unamuno.

7. El cap. VIII lleva al inicio en la segunda ed. un epígrafe sobre «La lírica mozárabe», debido al conocimiento producido hacía poco de las que don Dámaso denominó «cantigas de amigo mozárabes».

8. Por igual e inmediatamente después en ese capítulo, Lapesa incorpora su indagación acerca de los «francos» y el Fuero de Avilés.

9. No se hace referencia sin embargo (110-111/142-144) al provenzalismo español, aunque ya estaba publicada la investigación de Aebischer. El examen de la bibliografía nos dice que acaso quien primero se hizo cargo del asunto fue José Antonio Maravall en El concepto de España en la Edad Media (1954); allí debió de leerlo Américo Castro, quien habló del asunto unos lustros más tarde, y enseguida lo hizo don Rafael, incluso - con la comprensible impaciencia ante un asunto llamativo- en la prensa diaria (el diario $Y a$ ). 
10. El epígrafe sobre «El siglo $\mathrm{XIV} »$ se hace cargo en la nueva edición de páginas de $\mathrm{M}^{\mathrm{a}}$ Rosa Lida de Malkiel, de Antonio Badía.

11. El autor incorpora asimismo (142/182) la mención y la doctrina de don Américo en un artículo suyo de 1942.

12. En las dos ediciones consideradas (159/203), R. Lapesa escribe agudamente que en la lírica de Boscán y Garcilaso «la serena lentitud del endecasílabo se impone al vivaz ritmo octosilábico y sus abundantes rimas»: se trata de una manera intuitiva de manifestar cómo se oponen dos poéticas: la del verso largo italianista a la anterior del Cuatrocientos de un verso corto y rima repetida acuciantemente.

13. El párrafo inicial del cap. XIII aparece matizado (189/237): ya no se habla de una «casi completa fijación de la lengua» en el llamado «siglo de oro».

14. La nueva edición (192/241) suprime la idea de que «sólo desde este momento [h. 1600] puede hablarse de dialecto andaluz.

15. Lapesa ha podido acceder ya al libro de Keniston sobre la sintaxis del Quinientos, y hace uso de él (196/246).

16. En la creación de palabras el autor ejemplifica en las ediciones consideradas con el adjetivo «lopesco» (217/276); creemos preferible decir «lopeveguesco», según postulaba Menéndez Pidal y nosotros mismos procuramos hacer (si es que los llamados «correctores de estilo» de las editoriales no nos traicionan).

17. Se añade en la segunda ed. un epígrafe dedicado a «El canario» que faltaba en la anterior.

18. La segunda ed. trata como la primera de «El andalucismo del habla americana» (255 y ss./327 y ss.); se añade en la de 1950 cómo «hacia 1525 se escribe en Méjico maís [...]y en Cuba en 1539 çurto "surto"», y sólo en nota advierte el autor que estas muestras de confusión de sibilantes «apoya[n] mayor conexión entre el seseo andaluz y el americano, aunque éste posea caracteres propios y se generalizase algo más tarde». Resulta muy visible cómo don Rafael se muestra de manera tímida ante el rechazo que los ejemplos vistos por él de primeros del siglo XVI iban a suscitar en Amado Alonso, y procura no callarse la verdad de los datos dentro de una interpretación vacilante o prudente.

Según es sabido, nuestro autor revisó las ediciones posteriores de esta Historia de la lengua española hasta la edición última que hizo-la novena-. 